\title{
Genetic divergence among African cowpea lines based on morphoagronomic traits
}

\author{
E.M.R. Costa ${ }^{1}$, K.J. Damasceno-Silva ${ }^{2}$, M. M. Rocha ${ }^{2}$, A.M. Medeiros ${ }^{3}$ \\ and C.J. Anunciação Filho ${ }^{1}$ \\ ${ }^{1}$ Departamento de Agronomia, Universidade Federal Rural de Pernambuco, \\ Recife, PE, Brasil \\ ${ }^{2}$ Embrapa Meio-Norte, Teresina, PI, Brasil \\ ${ }^{3}$ Universidade Federal do Piauí, Teresina, PI, Brasil \\ Corresponding author: K.J. Damasceno-Silva \\ E-mail: kaesel.damasceno@embrapa.br
}

Genet. Mol. Res. 12 (4): 6773-6781 (2013)

Received February 14, 2013

Accepted August 7, 2013

Published December 16, 2013

DOI http://dx.doi.org/10.4238/2013.December.16.3

\begin{abstract}
The aim of this study was to estimate the genetic divergence between African cowpea lines from the Cowpea Germplasm Bank of Embrapa Meio-Norte, Brazil. The morphoagronomic diversity of 57 cowpea lines was assessed using multivariate analysis. The germplasm was evaluated in August 2009 using a randomized block design with three replications based on the following traits: number of pods per peduncle, pod length (PL), number of grains per pod (NGP), grain length (GRL), grain width, 100-grain weight (W100G), and yield. The heritability values of the traits PL, NGP, GRL, and W100G were all higher than $70 \%$, indicating the possibility of genetic progress with selection. The crosses between the lines IT82D-889 and IT89KD-245, IT85F-1380 and IT89KD-245, and IT89KD-245 and IT98K-1092-1 could result in promising genetic combinations. The characteristics that contributed most to genetic divergence were W100G (49.7\%), PL (16.7\%), GRL (12.0\%), and NGP (9.7\%).
\end{abstract}

Key words: Vigna unguiculata; Multivariate analysis; Cowpea accessions; Germplasm bank 


\section{INTRODUCTION}

Cowpea [Vigna unguiculata (L.) Walp.] is grown in all tropical regions over a total of at least 12.5 million hectares, with an annual worldwide production of over 3 million tons in 2007. Nigeria, Niger, and Brazil are the largest cowpea producers worldwide, accounting for $84.1 \%$ of the cropped area and $70.9 \%$ of global production (FAO, 2009).

Cowpea is a staple protein source for the population of the Northeastern region of Brazil (Bertini et al., 2009). This rather versatile crop is sold on the market in the form of dry grains, green grains or pods, flour for fried balls called "acarajé", and as seeds (Rocha et al., 2006). However, it is mostly sold in the form of dried beans, and is prepared either as a one-pot dish or together with rice (Mohammed et al., 2010).

Breeders have developed elite cultivars and improved lines of this crop, mainly by selection for higher yield, resistance to pests, diseases, nematodes, and weeds, and for drought and salinity tolerance (Ehlers and Hall, 1997). In Brazil, Embrapa Meio-Norte is in charge of actively collecting cowpea germplasm. Currently, the cowpea research network covers the North, Northeast, and Midwest regions, from the State of Roraima to Mato Grosso do Sul and from Pernambuco to Rondônia (Freire Filho et al., 2009).

Studies on genetic divergence provide important information by the characterization of accessions, enabling the identification of duplicates, variety protection, and selection of parents (Gupta and Gopalakrishna, 2009). Most of the information available on cowpea accessions in gene banks is based on morphological characteristics (Nkongolo, 2003). Several studies on the characterization of cowpea have been conducted using morphological (Vural and Karasu, 2007; Hegde and Mishra, 2009) or molecular characteristics (Aremu et al., 2007; Simon et al., 2007), or both (Ghalmi et al., 2009). This study aimed to estimate the genetic divergence between African cowpea lines from the Cowpea Germplasm Bank of Embrapa Meio-Norte.

\section{MATERIAL AND METHODS}

Of the cowpea lines ( $V$. unguiculata) from the Cowpea Germplasm Bank of Embrapa Meio-Norte, 57 were characterized for morphological and agronomic traits. Of these, 53 had been acquired by exchange with the International Institute of Tropical Agriculture (IITA), located in Nigeria, one line came from California (CB-27), one cultivar came from Peru (Vaina Blanca), one was an African line (TVx 5058 - 09C), and one line originated from the Cowpea breeding program of Embrapa Meio-Norte (Table 1).

The experiment was installed in August 2009 in an experimental area of Embrapa Meio-Norte, in Teresina, State of Piauí, in a randomized block design with 57 treatments and three replications. Each experimental plot consisted of one 4-m row, containing 16 plants spaced $0.25 \times 1.00 \mathrm{~m}$ apart. The following traits were assessed: number of pods per peduncle (NPP), pod length (PL), number of grains per pod (NGP), grain length (GRL), grain width (GRWi), 100-grain weight (W100G), and yield (YD).

The genetic variability between lines was determined by analysis of variance (ANOVA). Averages were compared with the Scott-Knott test at $5 \%$ probability. Genetic and environmental parameters were estimated, such as broad-sense heritability $\left(\mathrm{h}_{\mathrm{a}}^{2}\right)$, coefficients of genetic variation $\left(\mathrm{CV}_{\mathrm{g}}\right)$, and coefficients of environmental variation $\left(\mathrm{CV}_{\mathrm{e}}\right)$.

Genetic divergence was quantified with the unweighted pair-group method of arith- 
metic means (UPGMA) method, using the Mahalanobis' generalized distance $\left(\mathrm{D}^{2}\right)$ of as the similarity measure. Besides its use in the study of genetic diversity, $\mathrm{D}^{2}$ allows for quantification of the relative contribution of individual characteristics to overall divergence by using the criterion proposed by Singh (1981). The GENES software v. 2007.0.0 (Cruz, 2006) and a statistical program for ANOVA, SISVAR version 4.0 (Ferreira, 2000), were used for the analyses.

\begin{tabular}{|c|c|c|c|c|c|}
\hline Line number & Line & Origin & Line number & Line & Origin \\
\hline 1 & IT93K-452-1 & IITA & 30 & IT98K-1092-2 & IITA \\
\hline 2 & IT96D-610 & IITA & 31 & IT98K-1103-13 & IITA \\
\hline 3 & IT97K 568-18 & IITA & 32 & IT98D-1399 & IITA \\
\hline 4 & IT97K-1042-3 & IITA & 33 & IT99K-718-6 & IITA \\
\hline 5 & IT98K-205-8 & IITA & 34 & IT00K-901-5-2 & IITA \\
\hline 6 & IT98K-491-4 & IITA & 35 & IT00K-1207 & IITA \\
\hline 7 & IT98K-506-1 & IITA & 36 & IT00K-1217 & IITA \\
\hline 8 & IT98K-589-2 & IITA & 37 & IT00K-1263-2 & IITA \\
\hline 9 & IT98K-1111-1 & IITA & 38 & IT03K-316-1 & IITA \\
\hline 10 & IT99K-316-2 & IITA & 39 & IT84S-2135 & IITA \\
\hline 11 & IT99K-491-7 & IITA & 40 & IT89KD-245 & IITA \\
\hline 12 & IT99K-494-6 & IITA & 41 & IT87D-697-2 & IITA \\
\hline 13 & IT99K-529-2 & IITA & 42 & IT85F - 1380 & IITA \\
\hline 14 & IT99K-573-2-1 & IITA & 43 & IT85F-2687 & IITA \\
\hline 15 & IT99K-1060 & IITA & 44 & IT89KD-349 & IITA \\
\hline 16 & IT99K-1122 & IITA & 45 & IT96D-618 & IITA \\
\hline 17 & IT00K-898-5 & IITA & 46 & IT97K-568-14 & IITA \\
\hline 18 & IT00K-901-5-1 & IITA & 47 & IT98K-1101-5 & IITA \\
\hline 19 & IT00K-1263-1 & IITA & 48 & IT93K-93-10 & IITA \\
\hline 20 & IT93K-625 & IITA & 49 & IT92KD-279-3 & IITA \\
\hline 21 & IT97K-499-35 & IITA & 50 & IT87D-1627 & IITA \\
\hline 22 & IT97K-1069-6 & IITA & 51 & IT87D-611-3 & IITA \\
\hline 23 & IT98K-128-3 & IITA & 52 & IT91K-118-2 & IITA \\
\hline 24 & IT98K-128-4 & IITA & 53 & IT82D-889 & IITA \\
\hline 25 & IT98K-131-2 & IITA & 54 & CB-27 & California \\
\hline 26 & IT98K-205-9 & IITA & 55 & Vaina Blanca & Peru \\
\hline 27 & IT98K-205-15 & IITA & 56 & TVx $5058-09 \mathrm{C}$ & African line \\
\hline 28 & IT98K-503-1 & IITA & 57 & Mnc 03 720C- 11 & CPAMN \\
\hline 29 & IT98K-1092-1 & IITA & - & - & - \\
\hline
\end{tabular}

\section{RESULTS}

The mean squares were obtained from ANOVA for the quantitative traits (Table 2). The coefficient of variation values ranged from $5.83 \%$ for $\mathrm{W} 100 \mathrm{G}$ to $31.28 \%$ for YD.

Table 2. ANOVA of 7 quantitative traits assessed in cowpea lines, in an experiment in Teresina, PI, 2009.

\begin{tabular}{|c|c|c|c|c|}
\hline \multirow[t]{2}{*}{ Trait } & \multicolumn{2}{|c|}{ Mean squares } & \multirow[t]{2}{*}{ Mean } & \multirow[t]{2}{*}{$\mathrm{CV}(\%)$} \\
\hline & Lines & Error & & \\
\hline Pod length (PL, cm) & $9.61 * *$ & 1.45 & 16.36 & 7.35 \\
\hline Number of grains per pod (NGP) & $6.62 * *$ & 1.44 & 11.91 & 10.08 \\
\hline Grain length (GRL) & $2.00^{* *}$ & 0.32 & 8.36 & 6.78 \\
\hline Grain width (GRWi, mm) & $0.90^{* *}$ & 0.37 & 5.60 & 10.90 \\
\hline Number of pods per peduncle (NPP) & $0.34^{*}$ & 0.21 & 2.02 & 22.72 \\
\hline 100 -grain weight $(\mathrm{W} 100 \mathrm{G})$ & $25.67 * *$ & 1.05 & 17.54 & 5.83 \\
\hline Yield (YD, g) & $11930.53 * *$ & 5425.90 & 235.51 & 31.28 \\
\hline
\end{tabular}

**Significant at $1 \%$ probability by the $\mathrm{F}$-test. 
The trait means (Table 3) showed a variation of 1.3 for line IT98K-1101-5 and 3.0 for line IT99K-1060 for the NPP. The PL ranged from 11.80 to $20.92 \mathrm{~cm}$ for the lines IT98K-1092-1 and IT82D-889, respectively, reaching a mean of $16.36 \mathrm{~cm}$ between the lines.

\begin{tabular}{|c|c|c|c|c|c|c|c|c|}
\hline Line number & Lines & NPP & PL & NGP & GRL & GRWi & W100G & YD \\
\hline 1 & IT93K-452-1 & $2.30^{\mathrm{a}}$ & $15.20^{\mathrm{b}}$ & $11.77^{\mathrm{b}}$ & $8.33^{\mathrm{b}}$ & $5.95^{\mathrm{a}}$ & $18.70^{\mathrm{c}}$ & $187.70^{\mathrm{b}}$ \\
\hline 2 & IT96D-610 & $2.00^{\mathrm{a}}$ & $14.73^{\mathrm{c}}$ & $11.13^{\mathrm{b}}$ & $7.87^{b}$ & $4.51^{\mathrm{b}}$ & $16.07^{\mathrm{d}}$ & $365.50^{\mathrm{a}}$ \\
\hline 3 & IT97K 568-18 & $2.50^{\mathrm{a}}$ & $15.30^{\mathrm{b}}$ & $11.10^{\mathrm{b}}$ & $7.41^{\mathrm{c}}$ & $5.38^{\mathrm{a}}$ & $16.17^{\mathrm{d}}$ & $183.67^{\mathrm{b}}$ \\
\hline 4 & IT97K-1042-3 & $2.20^{\mathrm{a}}$ & $18.40^{\mathrm{a}}$ & $12.23^{\mathrm{a}}$ & $7.69^{b}$ & $5.52^{\mathrm{b}}$ & $14.20^{\mathrm{e}}$ & $194.47^{b}$ \\
\hline 5 & IT98K-205-8 & $2.50^{\mathrm{a}}$ & $15.13^{\mathrm{b}}$ & $12.73^{\mathrm{a}}$ & $8.36^{\mathrm{b}}$ & $5.59^{\mathrm{a}}$ & $15.87^{\mathrm{d}}$ & $251.60^{\mathrm{a}}$ \\
\hline 6 & IT98K-491-4 & $1.70^{\mathrm{a}}$ & $15.30^{\mathrm{b}}$ & $10.23^{\mathrm{b}}$ & $9.07^{\mathrm{a}}$ & $5.88^{a}$ & $21.33^{\mathrm{c}}$ & $248.93^{\mathrm{a}}$ \\
\hline 7 & IT98K-506-1 & $1.70^{\mathrm{a}}$ & $17.57^{\mathrm{a}}$ & $12.87^{\mathrm{a}}$ & $8.19^{\mathrm{b}}$ & $5.77^{\mathrm{a}}$ & $18.80^{\mathrm{c}}$ & $266.47^{\mathrm{a}}$ \\
\hline 8 & IT98K-589-2 & $1.80^{\mathrm{a}}$ & $14.60^{\mathrm{c}}$ & $10.63^{b}$ & $7.87^{b}$ & $5.81^{\mathrm{a}}$ & $16.13^{\mathrm{d}}$ & $175.40^{\mathrm{b}}$ \\
\hline 9 & IT98K-1111-1 & $2.00^{\mathrm{a}}$ & $15.00^{\mathrm{b}}$ & $11.25^{\mathrm{b}}$ & $7.21^{\mathrm{c}}$ & $6.28^{\mathrm{a}}$ & $18.55^{\mathrm{c}}$ & $157.70^{\mathrm{b}}$ \\
\hline 10 & IT99K-316-2 & $2.30^{\mathrm{a}}$ & $15.63^{\mathrm{b}}$ & $11.53^{\mathrm{b}}$ & $8.90^{\mathrm{a}}$ & $5.29^{\mathrm{b}}$ & $16.30^{\mathrm{d}}$ & $252.97^{\mathrm{a}}$ \\
\hline 11 & IT99K-491-7 & $2.00^{\mathrm{a}}$ & $14.43^{\mathrm{c}}$ & $11.40^{\mathrm{b}}$ & $8.02^{\mathrm{b}}$ & $5.12^{\mathrm{b}}$ & $13.27^{\mathrm{e}}$ & $290.53^{\mathrm{a}}$ \\
\hline 12 & IT99K-494-6 & $1.70^{\mathrm{a}}$ & $13.43^{\mathrm{c}}$ & $10.57^{\mathrm{b}}$ & $7.58^{\mathrm{b}}$ & $4.91^{\mathrm{b}}$ & $14.30^{\mathrm{e}}$ & $150.30^{\mathrm{b}}$ \\
\hline 13 & IT99K-529-2 & $1.80^{\mathrm{a}}$ & $18.63^{\mathrm{a}}$ & $12.27^{\mathrm{a}}$ & $9.70^{\mathrm{a}}$ & $6.35^{\mathrm{a}}$ & $24.87^{\mathrm{a}}$ & $218.63^{b}$ \\
\hline 14 & IT99K-573-2-1 & $2.20^{\mathrm{a}}$ & $18.03^{\mathrm{a}}$ & $11.40^{\mathrm{b}}$ & $8.77^{\mathrm{a}}$ & $5.93^{\mathrm{a}}$ & $20.70^{\mathrm{b}}$ & $172.13^{\mathrm{b}}$ \\
\hline 15 & IT99K-1060 & $3.00^{\mathrm{a}}$ & $14.83^{\mathrm{c}}$ & $11.83^{\mathrm{a}}$ & $9.29^{\mathrm{a}}$ & $5.44^{\mathrm{b}}$ & $15.60^{\mathrm{d}}$ & $181.27^{\mathrm{b}}$ \\
\hline 16 & IT99K-1122 & $1.80^{\mathrm{a}}$ & $13.47^{\mathrm{c}}$ & $14.63^{\mathrm{a}}$ & $6.75^{\mathrm{c}}$ & $5.47^{\mathrm{b}}$ & $14.00^{\mathrm{e}}$ & $305.90^{\mathrm{a}}$ \\
\hline 17 & IT00K-898-5 & $2.30^{\mathrm{a}}$ & $14.15^{\mathrm{c}}$ & $10.15^{\mathrm{b}}$ & $9.12^{\mathrm{a}}$ & $5.43^{\mathrm{b}}$ & $17.65^{\mathrm{d}}$ & $244.35^{\mathrm{a}}$ \\
\hline 18 & IT00K-901-5-1 & $2.00^{\mathrm{a}}$ & $16.97^{\mathrm{a}}$ & $13.80^{\mathrm{a}}$ & $8.60^{\mathrm{a}}$ & $5.55^{\mathrm{a}}$ & $18.33^{\mathrm{c}}$ & $253.47^{\mathrm{a}}$ \\
\hline 19 & IT00K-1263-1 & $1.70^{\mathrm{a}}$ & $17.83^{\mathrm{a}}$ & $10.90^{\mathrm{b}}$ & $9.44^{\mathrm{a}}$ & $6.24^{\mathrm{a}}$ & $19.93^{\mathrm{b}}$ & $350.13^{\mathrm{a}}$ \\
\hline 20 & IT93K-625 & $2.00^{\mathrm{a}}$ & $15.80^{\mathrm{b}}$ & $12.93^{\mathrm{a}}$ & $7.25^{\mathrm{b}}$ & $4.56^{\mathrm{b}}$ & $15.80^{\mathrm{d}}$ & $270.20^{\mathrm{a}}$ \\
\hline 21 & IT97K-499-35 & $1.80^{\mathrm{a}}$ & $17.33^{\mathrm{a}}$ & $13.63^{\mathrm{a}}$ & $8.02^{\mathrm{b}}$ & $5.42^{\mathrm{b}}$ & $18.07^{\mathrm{c}}$ & $225.80^{\mathrm{b}}$ \\
\hline 22 & IT97K-1069-6 & $1.80^{\mathrm{a}}$ & $17.40^{\mathrm{a}}$ & $12.60^{\mathrm{a}}$ & $8.05^{\mathrm{b}}$ & $5.12^{\mathrm{b}}$ & $18.17^{\mathrm{c}}$ & $270.80^{\mathrm{a}}$ \\
\hline 23 & IT98K-128-3 & $1.70^{\mathrm{a}}$ & $17.67^{\mathrm{a}}$ & $13.67^{\mathrm{a}}$ & $8.81^{\mathrm{a}}$ & $4.33^{\mathrm{b}}$ & $16.83^{\mathrm{d}}$ & $285.03^{\mathrm{a}}$ \\
\hline 24 & IT98K-128-4 & $2.20^{\mathrm{a}}$ & $17.80^{\mathrm{a}}$ & $12.53^{\mathrm{a}}$ & $7.86^{\mathrm{b}}$ & $5.15^{\mathrm{b}}$ & $13.93^{\mathrm{e}}$ & $163.67^{\mathrm{b}}$ \\
\hline 25 & IT98K-131-2 & $2.20^{\mathrm{a}}$ & $17.27^{\mathrm{a}}$ & $13.27^{\mathrm{a}}$ & $8.64^{\mathrm{a}}$ & $6.01^{\mathrm{a}}$ & $16.73^{\mathrm{d}}$ & $174.50^{\mathrm{b}}$ \\
\hline 26 & IT98K-205-9 & $2.20^{\mathrm{a}}$ & $16.07^{\mathrm{b}}$ & $11.37^{\mathrm{b}}$ & $8.74^{\mathrm{a}}$ & $5.70^{\mathrm{a}}$ & $18.43^{\mathrm{c}}$ & $205.87^{\mathrm{b}}$ \\
\hline 27 & IT98K-205-15 & $1.50^{\mathrm{a}}$ & $16.33^{\mathrm{b}}$ & $13.57^{\mathrm{a}}$ & $7.93^{\mathrm{b}}$ & $6.16^{\mathrm{a}}$ & $15.37^{\mathrm{d}}$ & $196.00^{\mathrm{b}}$ \\
\hline 28 & IT98K-503-1 & $2.20^{\mathrm{a}}$ & $13.33^{\mathrm{c}}$ & $9.50^{\mathrm{c}}$ & $9.21^{\mathrm{a}}$ & $5.99^{\mathrm{a}}$ & $20.13^{\mathrm{b}}$ & $358.80^{\mathrm{a}}$ \\
\hline 29 & IT98K-1092-1 & $2.30^{\mathrm{a}}$ & $11.80^{\mathrm{c}}$ & $13.70^{\mathrm{a}}$ & $6.29^{c}$ & $5.69^{\mathrm{a}}$ & $13.50^{\mathrm{e}}$ & $157.13^{\mathrm{b}}$ \\
\hline 30 & IT98K-1092-2 & $2.50^{\mathrm{a}}$ & $15.07^{\mathrm{b}}$ & $10.90^{\mathrm{b}}$ & $8.06^{\mathrm{b}}$ & $5.06^{\mathrm{a}}$ & $16.53^{\mathrm{d}}$ & $226.50^{\mathrm{b}}$ \\
\hline 31 & IT98K-1103-13 & $1.80^{\mathrm{a}}$ & $16.57^{\mathrm{b}}$ & $13.93^{\mathrm{a}}$ & $7.49^{c}$ & $5.49^{\mathrm{b}}$ & $18.07^{\mathrm{c}}$ & $231.87^{\mathrm{b}}$ \\
\hline 32 & IT98D-1399 & $1.80^{\mathrm{a}}$ & $16.15^{\mathrm{b}}$ & $12.65^{\mathrm{a}}$ & $9.14^{\mathrm{a}}$ & $5.85^{\mathrm{a}}$ & $19.35^{\mathrm{c}}$ & $194.75^{\mathrm{b}}$ \\
\hline 33 & IT99K-718-6 & $2.00^{\mathrm{a}}$ & $17.13^{\mathrm{a}}$ & $12.50^{\mathrm{a}}$ & $8.70^{\mathrm{a}}$ & $5.24^{\mathrm{b}}$ & $18.43^{\mathrm{c}}$ & $212.07^{\mathrm{b}}$ \\
\hline 34 & IT00K-901-5-2 & $2.70^{\mathrm{a}}$ & $16.63^{b}$ & $12.73^{\mathrm{a}}$ & $8.95^{\mathrm{a}}$ & $6.02^{\mathrm{a}}$ & $18.20^{c}$ & $275.53^{\mathrm{a}}$ \\
\hline 35 & IT00K-1207 & $1.80^{\mathrm{a}}$ & $14.80^{\mathrm{c}}$ & $12.70^{\mathrm{a}}$ & $6.53^{\mathrm{c}}$ & $6.21^{\mathrm{a}}$ & $15.13^{\mathrm{d}}$ & $201.13^{\mathrm{b}}$ \\
\hline 36 & IT00K-1217 & $2.00^{\mathrm{a}}$ & $15.13^{\mathrm{b}}$ & $11.93^{\mathrm{a}}$ & $8.49^{\mathrm{a}}$ & $5.66^{\mathrm{a}}$ & $15.07^{\mathrm{d}}$ & $146.40^{\mathrm{b}}$ \\
\hline 37 & IT00K-1263-2 & $1.70^{\mathrm{a}}$ & $19.77^{\mathrm{a}}$ & $11.33^{\mathrm{b}}$ & $9.42^{\mathrm{a}}$ & $6.18^{\mathrm{a}}$ & $20.23^{\mathrm{b}}$ & $305.10^{\mathrm{a}}$ \\
\hline 38 & IT03K-316-1 & $2.50^{\mathrm{a}}$ & $16.20^{\mathrm{b}}$ & $13.30^{\mathrm{a}}$ & $8.68^{\mathrm{a}}$ & $6.02^{\mathrm{a}}$ & $19.95^{\mathrm{b}}$ & $121.35^{\mathrm{b}}$ \\
\hline 39 & IT84S-2135 & $2.30^{\mathrm{a}}$ & $17.85^{\mathrm{a}}$ & $13.30^{\mathrm{a}}$ & $9.01^{\mathrm{a}}$ & $5.89^{\mathrm{a}}$ & $18.40^{\mathrm{c}}$ & $102.70^{\mathrm{b}}$ \\
\hline 40 & IT89KD-245 & $1.80^{\mathrm{a}}$ & $15.53^{\mathrm{b}}$ & $10.63^{\mathrm{b}}$ & $9.00^{\mathrm{a}}$ & $6.89^{\mathrm{a}}$ & $25.93^{\mathrm{a}}$ & $315.37^{\mathrm{a}}$ \\
\hline 41 & IT87D-697-2 & $1.50^{\mathrm{a}}$ & $14.23^{\mathrm{c}}$ & $11.70^{\mathrm{b}}$ & $7.74^{\mathrm{b}}$ & $6.47^{\mathrm{a}}$ & $17.47^{\mathrm{d}}$ & $388.07^{\mathrm{a}}$ \\
\hline 42 & IT $85 F-1380$ & $1.80^{\mathrm{a}}$ & $18.70^{\mathrm{a}}$ & $14.40^{\mathrm{a}}$ & $7.21^{\mathrm{c}}$ & $5.43^{\mathrm{b}}$ & $12.43^{\mathrm{e}}$ & $301.30^{\mathrm{a}}$ \\
\hline 43 & IT85F-2687 & $2.00^{\mathrm{a}}$ & $15.73^{\mathrm{b}}$ & $11.00^{\mathrm{b}}$ & $8.29^{\mathrm{b}}$ & $5.23^{\mathrm{b}}$ & $17.30^{\mathrm{d}}$ & $212.97^{\mathrm{b}}$ \\
\hline 44 & IT89KD-349 & $1.70^{\mathrm{a}}$ & $16.30^{\mathrm{b}}$ & $11.97^{\mathrm{b}}$ & $9.38^{\mathrm{a}}$ & $4.98^{\mathrm{b}}$ & $18.13^{\mathrm{c}}$ & $204.23^{\mathrm{b}}$ \\
\hline 45 & IT96D-618 & $2.20^{\mathrm{a}}$ & $16.10^{\mathrm{b}}$ & $10.40^{\mathrm{b}}$ & $9.35^{\mathrm{a}}$ & $5.98^{\mathrm{a}}$ & $19.73^{\mathrm{b}}$ & $310.30^{\mathrm{a}}$ \\
\hline 46 & IT97K-568-14 & $2.00^{\mathrm{a}}$ & $18.03^{\mathrm{a}}$ & $14.77^{\mathrm{a}}$ & $8.17^{b}$ & $5.77^{\mathrm{a}}$ & $18.27^{\mathrm{c}}$ & $290.77^{\mathrm{a}}$ \\
\hline 47 & IT98K-1101-5 & $1.30^{\mathrm{a}}$ & $16.77^{\mathrm{a}}$ & $7.63^{c}$ & $9.83^{\mathrm{a}}$ & $5.89^{\mathrm{a}}$ & $22.43^{\mathrm{a}}$ & $227.07^{\mathrm{b}}$ \\
\hline 48 & IT93K-93-10 & $1.50^{\mathrm{a}}$ & $18.83^{\mathrm{a}}$ & $12.60^{\mathrm{a}}$ & $8.21^{\mathrm{b}}$ & $5.96^{\mathrm{a}}$ & $15.50^{\mathrm{d}}$ & $358.40^{\mathrm{a}}$ \\
\hline 49 & IT92KD-279-3 & $2.20^{\mathrm{a}}$ & $16.20^{\mathrm{b}}$ & $12.00^{\mathrm{a}}$ & $7.29^{c}$ & $4.26^{\mathrm{b}}$ & $13.43^{\mathrm{e}}$ & $254.40^{\mathrm{a}}$ \\
\hline 50 & IT87D-1627 & $2.20^{\mathrm{a}}$ & $17.83^{\mathrm{a}}$ & $12.47^{\mathrm{a}}$ & $8.15^{b}$ & $5.00^{\mathrm{b}}$ & $15.43^{\mathrm{d}}$ & $253.03^{\mathrm{a}}$ \\
\hline 51 & IT87D-611-3 & $2.20^{\mathrm{a}}$ & $17.97^{\mathrm{a}}$ & $11.70^{\mathrm{b}}$ & $7.71^{\mathrm{b}}$ & $6.03^{\mathrm{a}}$ & $14.57^{\mathrm{e}}$ & $203.57^{\mathrm{b}}$ \\
\hline 52 & IT91K-118-2 & $2.00^{\mathrm{a}}$ & $20.60^{\mathrm{a}}$ & $11.97^{\mathrm{a}}$ & $9.14^{\mathrm{a}}$ & $6.22^{\mathrm{a}}$ & $16.23^{\mathrm{d}}$ & $207.17^{b}$ \\
\hline 53 & IT82D-889 & $1.80^{\mathrm{a}}$ & $20.92^{\mathrm{a}}$ & $12.87^{\mathrm{a}}$ & $8.37^{\mathrm{b}}$ & $4.51^{\mathrm{b}}$ & $13.13^{\mathrm{e}}$ & $189.43^{\mathrm{b}}$ \\
\hline 54 & CB-27 & $2.00^{\mathrm{a}}$ & $16.45^{\mathrm{b}}$ & $10.37^{\mathrm{b}}$ & $9.14^{\mathrm{a}}$ & $5.70^{\mathrm{a}}$ & $20.33^{\mathrm{b}}$ & $263.50^{\mathrm{b}}$ \\
\hline 55 & Vaina Blanca & $2.00^{\mathrm{a}}$ & $16.40^{\mathrm{b}}$ & $9.00^{c}$ & $9.50^{\mathrm{a}}$ & $5.90^{\mathrm{a}}$ & $21.45^{\mathrm{b}}$ & $210.15^{b}$ \\
\hline 56 & TVX 5058 - 09C & $2.90^{\mathrm{a}}$ & $15.40^{\mathrm{b}}$ & $10.35^{\mathrm{b}}$ & $7.79^{b}$ & $5.40^{\mathrm{b}}$ & $16.92^{\mathrm{d}}$ & $237.53^{\mathrm{b}}$ \\
\hline 57 & MNC $03720 \mathrm{C}-11$ & $2.00^{\mathrm{a}}$ & $15.83^{\mathrm{b}}$ & $8.43^{\mathrm{c}}$ & $9.01^{\mathrm{a}}$ & $5.80^{\mathrm{a}}$ & $23.95^{\mathrm{a}}$ & $220.70^{\mathrm{b}}$ \\
\hline Mean & & 2.02 & 16.36 & 11.91 & 8.36 & 5.60 & 17.54 & 235.51 \\
\hline
\end{tabular}

For abbreviations, see Table 2. Means followed by the same letter do not differ from each other at $5 \%$ probability. 
The NGP ranged from 7.63 to 14.77 for the lines IT98K-1101-5 and IT97K-568-14, with an average of 11.91 grains per pod for all lines. GRL values varied from 6.29 to $9.83 \mathrm{~mm}$ for the lines IT98K-1101-5 and IT98K-1092-1, respectively. The mean GRWi of the lines was $5.60 \mathrm{~mm}$. For lines with greater GRL and GRWi, a higher grain weight was observed, which increased the W100G value. W100G ranged from 12.43 to $25.93 \mathrm{~g}$ for the lines IT85F-1380 and IT89KD-245. The greatest grain length $(9.83 \mathrm{~mm})$ and one of the highest W100G values $(22.43 \mathrm{~g})$ were observed for line IT98K-1092-1.

The YD ranged from $102.70 \mathrm{~g}$ (line IT84S-2135) to $388.07 \mathrm{~g}$ (line IT87D-697-2). Other lines also produced YD over $300 \mathrm{~g}$, i.e., IT85F-1380 (301.30 g), IT99K-1122 (305.90 g), IT96D-618 (310.30 g), IT89KD-245 (315.37 g), IT00K-1263-1 (350.13 g), IT93K-93-10 (358.40 g), IT98K-503-1 (358.80 g), IT96D-610 (365.50 g), and IT87D-697-2 (388.07 g).

Estimates of genetic parameters for traits (Table 4) showed that the $\mathrm{CV}_{\mathrm{g}}$ was highest for the traits YD (19.77\%) and W100G (16.33\%). The relationship between $\mathrm{CV}_{\mathrm{g}}^{\mathrm{g}}$ and $\mathrm{CV}_{\mathrm{e}}$ was high for most traits (>1.0), except for GRWi (0.69), NPP (0.45), and YD (0.63). The heritability estimates ranged between 37.38 and $95.92 \%$ for NPP and W100G, respectively.

Table 4. Estimates of the coefficient of variation genetic $\left(\mathrm{CV}_{\mathrm{g}}\right)$, heritability $\left(\mathrm{h}_{\mathrm{a}}^{2}\right)$ and the ratio between the genetic and environmental coefficient of variation $\left(\mathrm{CV}_{\mathrm{g}} / \mathrm{CV}_{\mathrm{e}}\right)$ corresponding to the 7 quantitative traits, derived from the expectations of the mean squares of ANOVA (Teresina, PI, 2009).

\begin{tabular}{lccc}
\hline Trait & $\mathrm{CV}_{\mathrm{g}}(\%)$ & $\mathrm{CV}_{\mathrm{g}} / \mathrm{Cv}_{\mathrm{e}}$ & $\mathrm{h}_{\mathrm{a}}^{2}(\%)$ \\
\hline PL & 10.08 & 1.37 & 84.95 \\
NGP & 11.03 & 1.09 & 78.23 \\
GRL & 8.95 & 1.32 & 83.96 \\
GRWi & 7.48 & 0.69 & 58.58 \\
NPP & 10.14 & 0.45 & 37.38 \\
W100G & 16.33 & 2.80 & 95.92 \\
YD & 19.77 & 0.63 & 54.52 \\
\hline
\end{tabular}

For abbreviations, see Table 2.

According to $\mathrm{D}^{2}$ (Figure 1), the dissimilarity measures were highest between the line pairs IT82D-889 and IT89KD-245 (221.35), IT85F-1380 and IT89KD-245 (206.04), and IT89KD-245 and IT98K-1092-1 (200.51). The shortest dissimilarity distances were found between the lines IT98K-128-4 and IT97K-1042-3 (1.21), IT97K-1069-6 and IT98K-506-1 (1.39), IT97K-1069-6 and IT97K-499-35 (1.41), IT97K-499-35 and IT00K-901-5-1 (1.65), and IT97K-499-35 and IT98K-506-1 (1.91).

Based on the UPGMA analysis, the lines were distributed into four distinct groups, which consisted of few lines, with the exception of the fourth group that contained $71 \%$ of the genotypes studied (Table 5 and Figure 2).

The characteristics with highest contribution to divergence, according to the criteria proposed by Singh (1981), were W100G (49.7\%), PL (16.7\%), GRL (12.0\%), and NGP (9.7\%), which together accounted for $88.1 \%$ of the variability between the lines tested (Table 6).

\section{DISCUSSION}

Genetic variabilities for all traits were observed between cowpea lines (Table 2). The coefficient of variation, indicated good experimental precision in the analysis of all traits, even the yield-related traits, which are complex and relatively more susceptible to environmental variation (Allard, 1971). 


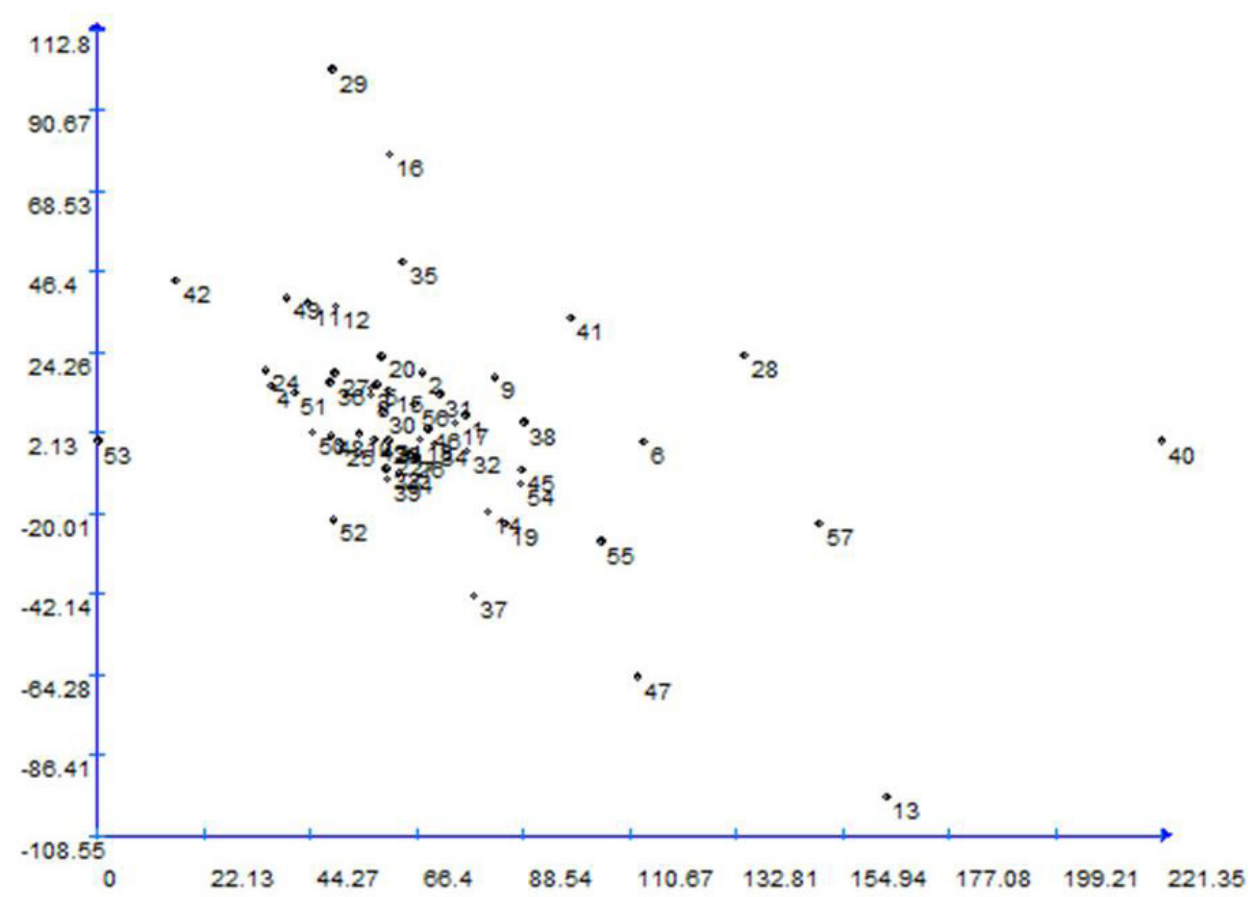

Figure 1. Estimates of Mahalanobis' generalized distances between 57 cowpea lines represented in a bidimensional dispersion graph. Teresina, PI, 2009. Lines with their identification number are listed in Table 1.

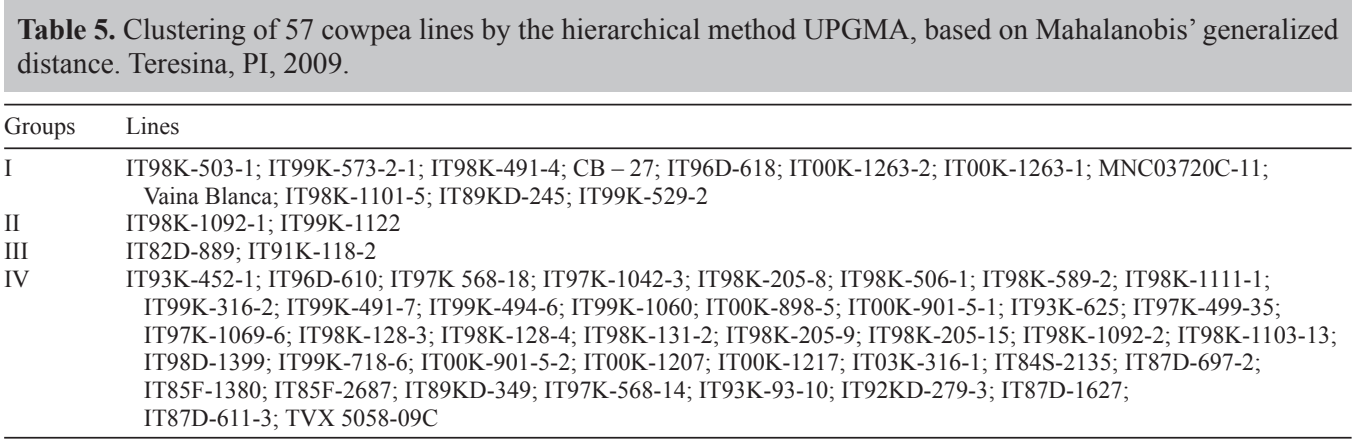

External pod characteristics are important, especially in the case of consumption of unripe grain. According to Souza et al. (2006), cowpea pods are sold in bunches on the market, increasing the relevance of certain external characteristics, especially pod length and transverse diameter, which reflect the number and size of the green beans.

Mishili et al. (2009) surveyed consumer preferences regarding the characteristics and value of cowpea grain in the African markets of Nigeria, Ghana, and Mali and found that consumers preferred larger grains and were willing to pay higher prices for such grains. Similar results to those of the present study were previously reported for W100G of cowpea. Torres et 


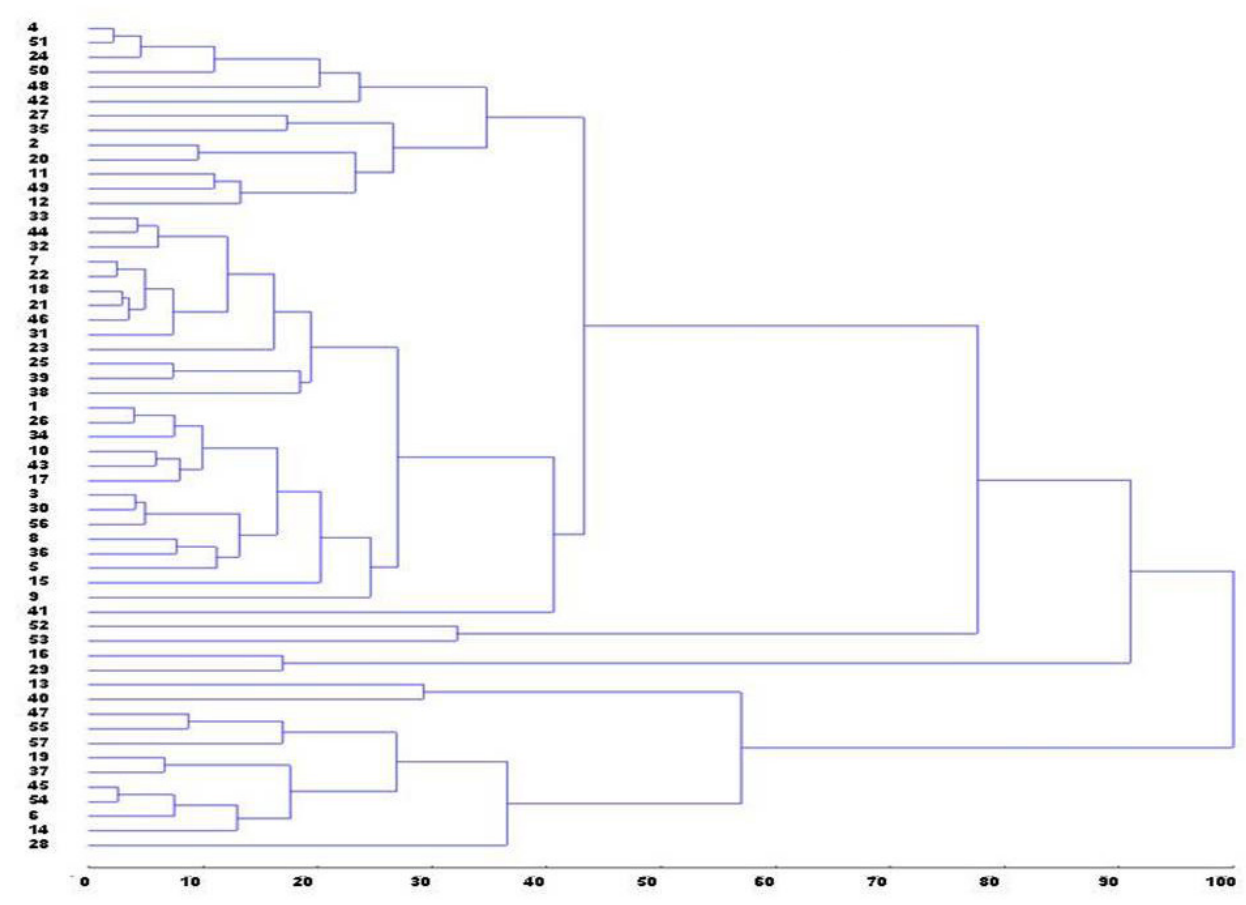

Figure 2. Representative dendrogram of genetic divergence among 57 cowpea lines obtained by the UPGMA method. Teresina, PI, 2009. Lines with their identification number are listed in Table 1.

Table 6. Relative contribution of the traits to divergence proposed by Singh (1981) (Teresina, PI, 2009).

\begin{tabular}{lr}
\hline Trait & $\mathrm{S}_{\mathrm{j}}(\%)$ \\
\hline Pod length & 16.69 \\
Number of grains per pod & 9.70 \\
Grain length & 11.98 \\
Grain width & 3.38 \\
Number of pods per peduncle & 3.44 \\
Grain weight & 49.68 \\
Yield & 5.09 \\
\hline
\end{tabular}

al. (2008) evaluated 10 cowpea accessions in the soil-climatic conditions of Mossoró, RN, and reported that the average W100G ranged from $15.86 \mathrm{~g}$ (Pingo-de-ouro) to $23.47 \mathrm{~g}$ (Costelade-vaca).

Bertini et al. (2009) evaluated 16 cowpea accessions of the germplasm bank of Universidade Federal do Ceará, and found a variation in grain yield, that is, 35.65-328.15 g. The YD was highest for accession CE-871, and the other accessions with high YD were CE-79 (312.29 g), CE-93 (292.73 g), and CE-873 (323.03 g). According to Lal et al. (2007), breeding programs involving the selection of parents based on genetic divergence in YD components can produce transgressive segregants with good YD potential.

The heritability for most traits was higher than $50 \%$, suggesting the possibility of genetic progress by selection for these characteristics, including YD with a heritability of 
$54.52 \%$. Lopes et al. (2001) evaluated 28 cowpea lines based on agronomic traits and found relatively high heritability values for the characteristics PL $(75.66 \%)$ and W100G (81.74\%), and intermediate values for YD $(34.15 \%)$.

According to $\mathrm{D}^{2}$, the line IT89KD-245 was the most divergent among all lines. According to Oliveira et al. (2007), crosses between the most divergent accessions can increase the variability, and possibly result in the establishment of superior plants. Furthermore, crosses between similar groups may not be well suited for obtaining superior genotypes in segregating generations (Bertini et al., 2009).

The recommendation of crosses between lines of different groups can help obtain favorable gene combinations, provided that the recommended lines have desirable agronomic traits for increasing the yield capacity. In this sense, crosses between the lines IT82D-889 and IT89KD-245, IT85F-1380 and IT89KD-245, and IT89KD-245 and IT98K-1092-1 appear to be promising.

Dias et al. (2009) assessed the genetic divergence between 28 cowpea lines from the germplasm bank of Universidade Federal do Ceará based on agronomic traits, and as well as in the present study, they observed that $\mathrm{W} 100 \mathrm{G}$ was one of the most important traits contributing to genetic divergence. Oliveira et al. (2003) evaluated the influence of nine phenotypic traits on grain yield per plant based on genetic correlations, and identified that the average NPP followed by W100G were the most important traits in the selection for cowpea grain yield.

\section{ACKNOWLEDGMENTS}

The authors thank Embrapa Meio-Norte for funding and other support of this research and Conselho Nacional de Desenvolvimento Científico e Tecnológico (CNPq) for granting a scholarship.

\section{REFERENCES}

Allard RW (1971). Princípios do Melhoramento Genético de Plantas. USAID, Rio de Janeiro.

Aremu CO, Adebayo MA, Ariyo OJ and Adewale BB (2007). Classification of genetic diversity and choice of parents for hybridization in cowpea Vigna unguiculata (L.) Walp for humid savanna ecology. Afr. J. Biotechnol. 6: $2333-2339$.

Bertini CHCM, Teófilo EM and Dias FTC (2009). Divergência genética entre acessos de feijão-caupi do banco de germoplasma da UFC. Rev. Ciênc. Agron. 40: 99-105.

Cruz CD (2006). Programa GENES: Aplicativo Computacional em Genética e Estatística. Version 2007.0.0. Available at [http:// www.ufv.br/dbg/genes/genes.htm]. Accessed August 27, 2010.

Dias FTC, Silva PM and Bertini CHCM (2009). Genetic divergence in cowpea genotypes with upright growth and early cycle. Crop Breed. Appl. Biotechnol. 9: 253-259.

Ehlers JD and Hall AE (1997). Cowpea (Vigna unguiculata L. Walp.). Field Crop Res. 53: 187-204.

FAO (2009). FAOSTAT. Crops. Cow Peas, Dry. Available at [http://faostat.fao.org/site/567/DesktopDefault. aspx?PageID=567\#ancor]. Accessed October 4, 2009.

Ferreira DF (2000). Análises Estatísticas por Meio do Sisvar para Windows Versão 4.0. In: 45a Reunião Anual da Região Brasileira da Sociedade Internacional de Biometria. UFSCar, São Carlos, 255-258.

Freire Filho FR, Rocha MM, Silva KJD and Ribeiro VQ (2009). O Melhoramento Genético no Contexto Atual. In: Simpósio Nordestino de Genética e Melhoramento de Plantas em 2009. Embrapa Agroindústria Tropical, Fortaleza, 25-59.

Ghalmi N, Malice M, Jacquemin JM, Ounane SM, et al. (2009). Morphological and molecular diversity within Algerian cowpea (Vigna unguiculata (L.) Walp.) landraces. Genet. Resour. Crop. Evol. 57: 371-386.

Gupta SK and Gopalakrishna T (2009). Genetic diversity analysis in blackgram (Vigna mungo (L.) Hepper) using AFLP and transferable microsatellite markers from azuki bean (Vigna angularis (Willd.) Ohwi \& Ohashi). Genome 52: $120-129$. 
Hegde VS and Mishra SK (2009). Landraces of cowpea, Vigna unguiculata (L.) Walp., as potential sources of genes for unique characters in breeding. Genet. Resour. Crop. Evol. 56: 615-627.

Lal H, Rai M, Karan S, Verma A, et al. (2007). Multivariate hierarchical clustering of cowpea germplasm [Vigna unguiculata (L.) Walp.]. Acta Hort. 752: 413-416.

Lopes ACA, Freire Filho FR, Silva RBQ, Campos FFL, et al. (2001). Variabilidade e correlações entre caracteres agronômicos em caupi (Vigna unguiculata). Pesq. Agropec. Bras. 36: 515-520.

Mishili FJ, Fulton J, Shehu M, Kushwaha S, et al. (2009). Consumer preferences for quality characteristics along the cowpea value chain in Nigeria, Ghana, and Mali. Agribusiness 25: 16-35.

Mohammed MS, Russom Z and Abdul SD (2010). Inheritance of hairiness and pod shattering, heritability and correlation studies in crosses between cultivated cowpea (Vigna unguiculata (L.) Walp.) and its wild (var. pubescens) relative. Euphytica 171: 397-407.

Nkongolo KK (2003). Genetic characterization of Malawian cowpea (Vigna unguiculata (L.) Walp) landraces: diversity and gene flow among accessions. Euphytica 129: 219-228.

Oliveira FJ, Anunciação Filho CJ, Bastos GQ, Reis OD, et al. (2003). Caracteres agronômicos aplicados na seleção de cultivares de caupi. Rev. Ciênc. Agron. 34: 5-11.

Oliveira MSP, Ferreira DF and Santos JB (2007). Divergência genética entre acessos de açaizeiro fundamentada em descritores morfoagronômicos. Pesq. Agropec. Bras. 42: 501-506.

Rocha MM, Freire-Filho FR, Ramos SSR, Ribeiro VQ, et al (2006). Avaliação Agronômica de Genótipos de Feijão-Caupi para Produção de Grãos Verdes. (Embrapa Meio-Norte. Boletim de Pesquisa e Desenvolvimento, n. 67). Embrapa Meio-Norte, Teresina. Available at [http:// www.cpamn.embrapa.br]. Accessed January 3, 2010.

Simon MV, Benko-Iseppon AM, Resende LV, Winter P, et al. (2007). Genetic diversity and phylogenetic relationships in Vigna Savi germplasm revealed by DNA amplification fingerprinting. Genome 50: 538-547.

Singh D (1981). The relative importance of characters affecting genetic divergence. Indian J. Genet. Plant Breed. 41: 237-245.

Souza FF, Freire-Filho FR, Rocha MM and Costa EFM (2006). Genótipos de feijão-caupi para cultivo nas várzeas do Rio Madeira, em Rondônia. (Comunicado Técnico, n. 308). Embrapa Rondônia, Porto Velho. Available at [http://www. cpafro.embrapa.br]. Accessed January 3, 2010.

Torres SB, Oliveira FN, Oliveira RC and Fernandes JB (2008). Produtividade e morfologia de acessos de caupi, em Mossoró, RN. Hortic. Bras. 26: 537-539.

Vural H and Karasu A (2007). Variability studies in cowpea (Vigna unguiculata [L.] Walp.) varieties grown in Isparta, Turkey. UDO Ag. 7: 29-34. 